\title{
The General Principles of Establishment of Regulations as a Testing Tool of Harmonization Policy of Local Regulation Product in Indonesia
}

\author{
Abdul Aziz Nasihuddin \\ Jenderal Soedirman University \\ ziz_lingk@yahoo.com
}

\author{
Tedi Sudrajat \\ Jenderal Soedirman University \\ tedi.unsoed@gmail.com
}

\author{
Sri Wahyu Handayani \\ Jenderal Soedirman University \\ ayufh27@gmail.com
}

\begin{abstract}
The varied matters in Local Governments of Indonesia create authority implication in the establishment of local regulation products. The unclear standards and criteria in the establishment of local regulation, in this case are Local Regulations and Local Head Regulations, have led to problems regarding the type, hierarchy and content materials of these two regulation products. Their intersections cause some implications, Firstly, many freshlystipulated regulations replaced with new ones; and Secondly, many of the regulations established by local governments are revoked by the central government because the content are conflict with the higher regulations. This paper will discuss the ideal policies in establishing local regulation products which refer to the General Principles of Establishment of Regulations. The outcome of these policies would be the determination of norms, standards, procedures and criteria in establishing local regulation products based on the compatibility of types, hierarchy and content materials of laws as set forth in Law No. 12 Year 2011 on Establishment of Regulations.
\end{abstract}

Keywords: local regulation, types, hierarchy and content materials

\section{INTRODUCTION}

According to Law No. 23 Year 2014 concerning Local Government, Local Autonomy is the rights, authorities, and obligations of an autonomous region to independently organize and administer the local Government's affairs and people's interest within the system of Unitary State of the Republic of Indonesia. In relation to the division of affairs, Law No. 23 Year 2014 concerning Local Government divides the Government Affairs into 3 (three) categories, namely absolute government affairs, concurrent government affairs, and general government affairs. The absolute government affairs are those government affairs which fall completely under the authority of Central Government. The concurrent government affairs are those government affairs which are divided between the Central Government and Province government affairs divided between the Central Government and Province and
Regency/Municipality governments, they are divided further into mandatory and optional government affairs.

To the affairs governed by the government, within the context of local autonomy, there are these concurrent affairs to organize and administer the region's respective internal affairs. In terms of organizing, the Local governments have the authority to make regulations in their regions in the form of Local Regulations and Local Head Regulations. The function of organizing within the Local government is intended to create its authority in case of dealing with people's peace and order in regions as the circumstance may require in the society wherein the regulations are applied. However, it is not always the case, since the great authority bestowed within autonomy scope creates new problems to the regulations of law subsystem, particularly in their process of establishment.

Those establishing the Local Regulations still find it difficult to get the right formula to draft the appropriate local law products so far. It has been common that some Local Regulations are too technical, making themselves similar to Local Head Regulations. On the other hand, many of the types, hierarchy and content materials of Local Head Regulations which should actually be governed in Local Regulations, for the purpose of facilitating the process, are made in the form of Local Head Regulations. Based on this fact, this paper will discuss Firstly, the direction of national legal development in the establishment of regulations; and Secondly, the ideal form of policies in harmonizing law products in Indonesia.

\section{METHOD}

The method used is Normative Juridical approach which use law and analytical approach. In order to achieve legal harmonization, the evaluation and analysis of laws and regulations will relate to the types, hierarchy and content materialsof the local regulation, either vertically or horizontally.

For the analytical method, the authors used normative qualitative analysis through grammatical interpretive model and systematic interpretation. The results of the analysis are presented comprehensively, all inclusive and systematic using deductive logic. 


\section{RESULT}

Direction of National Legal Development Based on the General Principles of Establishment of Regulations

The direction of national legal development is integrated with the direction of developments which require synchronization. Direction of legal development departs from the general ideas in the 1945 Constitution of the Republic of Indonesia (hereinafter UUD NRI Year 1945). Legal development is not identical and cannot be made identical with create regulations. In this regard, establishing many regulations does not mean establishing the law because a state of law is not a state of regulation. Therefore, certain spirit is needed to allow this order to have some capacity. [1]

As it is known, when it comes to national legal development, it should of course consider UUD NRI Year 1945, wherein the state and country's ideology formulae are contained, the one in Indonesia referred to as Pancasila ideology. In common doctrinary understanding, an ideology should "illuminate" the formulation of articles in the body of UUD NRI Year 1945 and regulations of law below it. Speaking about the national legal structure, when it is associated with stufen theorie, these legal norms consist of some tiers and layers in a structured order hierarchy, where a lower norm should be sourced from the higher ones, this goes on and on until it reaches a norm which cannot be traced further and of hypothetical and fictitious nature, i.e. the basic norm (Grundnorm). In this case, an ideal legal norm always has two faces (das Doppelte Rechtssantlitz). Upwards, this legal norm is sourced and based on the norms above it, yet downwards it also becomes the basis and source for the legal norms below it. Thus, a legal norm has a relative effective term (rechtskracht). This is because the effective term of a legal norm depends on the legal norms above it, hence when these legal norms above it are revoked or nullified the legal norms below them will be revoked and nullified as well. [2]

Based on Articles 7 and 8 of Law No. 12 Year 2011 concerning the Establishment of Regulations of Law, the types and hierarchy of regulations of law include:

1. 1945 Constitution of the Republic of Indonesia;

2. People's Consultative Assembly's Ruling;

3. Laws/Government Regulation in lieu of Law;

4. Government Regulation;

5. Presidential Regulation;

6. Regulations of Province;

7. Regulations of Regency/Municipality.

The regulations determined by People's Consultative Assembly, Houseof Representatives, Local Representative Council, Supreme Court, Constitutional Court, Audit Board of Indonesia, Judicial Commission, Bank of Indonesia, Ministers, agencies, institutions, or commissions of the same level established under Law or by the Government under the Law, House of Province Representatives, Governor, House of Regency/
Municipality Representatives, Regent/Mayor, Village Chief and alike.

As a consequence, when there is a law product conflicting with the spirit and soul of philosophical, juridical and sociological bases, then based on the General Principles of Establishment of Law, any one of these law products shall have no binding legal power by such parameters as:

1. A regulation of laws of lower rank shall never conflict with any regulation of laws of higher rank;

2. A regulation of laws of lower rank can only be revoked on the power of regulation of laws of the same or higher rank;

3. A regulation of laws of lower rank, if its materials conflict with the regulation of laws of higher rank cannot be enforced.

To the 3 (three) binding consequences of regulation of laws, as referred to in Article 7 paragraph (1) jo Article 8 paragraph (2) Law No. 12 Year 2011, any regulation of lower ranks (such as Local Head Regulation) shall never conflict with any regulation of higher rank (such as Local Regulations).

Considering the foregoing, the development of legal substance is a comprehensive concept that all stakeholders of legal development at national level collectively aim at. The efforts are performed through coordination among all stakeholders in order to realize a law product which complies with the provisions of regulation of laws, by still taking a good care of the substance of regulation to keep it from overlapping with others and to prevent any inconsistency of regulation of laws from manifesting. The method used in order to achieve this law harmonization is to evaluate and analyze the regulations of laws related to regulations of laws, be it vertically or horizontally. This regulation harmonization effort is based on the general principles of establishment of regulations of law. [3]

\section{The Ideal Policy in Harmonizing Local Law Products}

Under Article 18 paragraph (6) of UUD NRI Year 1945 , every region in Indonesia is authorized to manage and administer their internal affairs, also known as autonomy. In this case, it is directed towards the relationship that local governments serves as part of a strategic approach to consolidating Indonesia's decentralization.[4]

In relation to the establishment of regulations in regions, there are 2 (two) law products which support each other in managing the autonomy, which areLocal Regulations and Local Head Regulations. Functionally, Local Regulations is used as a legal means in the case of, Firstly, the policy instrument to perform the local autonomy as mandated in UUD NRI Year 1945; Secondly, it serves as the place to accommodate the specificity and diversity of regions; andThirdly, it serves as the tools for development in improving the region's welfare. Meanwhile, the Local Head Regulations have 
the function to detail Local Government Regulation and give procedural guideline. [5] With such a role, it means thatLocal Head Regulations is a form of delegated legislation product. [6]

In regard to the establishment of Local Regulations, in order to eradicate any disharmony, some juridical requirements below shall be taken:

1. Made or established by an authorized organ, it means a regulation of laws should be made by an official or agency who has the authority for that matters. This requirement, when it is not complied with, has a consequence that the law shall be void by law.

2. Compatibility between the form/type of regulation of laws with the content materials to be governed, it means any incompatibility of form/type can be a reason for revoking the said regulation of laws.

3. Existence of predetermined procedure and methods of establishment, it means a regulation of laws should be established through a certain procedure and method which have been determined.

4. No conflict with regulation of laws of higher rank, according to stufenbau theory, a regulation of laws contains hierarchical legal norms. It means a regulation of laws of higher rank is a grundnorm (basic norm) for any regulation of laws of lower rank.[6]

Borrowing the Hans Kelsen's [7] framework of thinking, hierarchically a regulation of laws of lower rank shall contain content materials which functionally explain or make operable the regulation of laws of higher rank. Local Head Regulations should also be this way, to serve only the function of explaining further the mandate from the Local Regulations. This is what is called as super- and sub-ordinate relationship in normative hierarchy.

Taking the aforesaid into account, the existence of Local Regulations and Local Head Regulations, in essence, constitutes a result of decentralization principle in administering Local governments and is an integral part of a national legal system. When conflict exists between the two, it should then be tested materially and formally. Serving as the testing tools are:

1. Conflicting with any regulation as stipulated by the government apparatuses of higher rank;

2. Conflicting with general principles of gnatural justice;

3. Conflicting with general principles of good regulations in order to prevent any abuse.

4. Conflicting with general interest, conflicting with an interest which, in the opinion of government's apparatuses authorized to revoke it, is greater than the interest governed in the decision being revoked or conflicting with general policies implemented by the central government.

Considering the above matters, within legal development planning spectrum, ideally the planning of establishment of regulations shall not intersect one another because of the clash of logic of governmental processes using the Contrarius Actus principle, which means that in the concept of government the party entitled to revoke a legal action is the one who made it. Therefore, the result of evaluation from Minister of Home Affairs and Governor takes the form of order for revocation.

In Indonesia, the guideline for administering Local Government is set forth in Law Number 23 year 2014 which is then detailed into some Government Regulations and Ministerial Regulations to evaluate any possible law conflict. For this purpose, the monitoring effort is done through 2 (two) actions, namely confirmation and approval. Confirmation of bylaws is not merely about examining the legal aspect, rather the goal to be achieved shall be whether or not it is something needed from the perspective of local circumstance. Meanwhile, an approval is made towards a plan or proposal submitted by the region. On this basis, within the context of monitoring the substance of Local Regulation, the Government of Indonesia should make some policies to strengthen the executive preview mechanism over Local law product drafts. Only upon approval can the Local law product be implemented.

\section{CONCLUSION}

The effort to harmonize is taken by associating the legal issues with the material and formal principles. The policies which should be made in the effort of harmonizing local law products are to perform monitoring in terms of confirmation and approval. Based on this condition, it is then clear that Local Regulation has higher rank than Local Head Regulation. As a logical consequence of this fact, the substance in Local Head Regulations which derives from the orders of Local Regulation shall never conflict with Local Regulation which underlies its establishment. For Local Head Regulation made under an authority, it should be seen within the context of authority owned by Local Heads. In other words, it is about whether or not the Local Heads are embedded with the authority to make that Local Head Regulation, even if they are not ordered by any regulation of laws of higher rank.

\section{REFERENCES}

[1] Patrialis Akbar, "Arah Pembangunan Hukum Nasional Menurut UUD NRI 1945", accessed at https://fh.umj.ac.id/Arah-Pembangunan-HukumNasional-Menurut-Undang-Undang-Dasar-NegaraRepublik-Indonesia-Tahun-1945/, downloaded on May 3, 2017

[2] Maria Farida Indrati, "Ilmu Perundang-Undangan: Dasar-Dasar dan Pembentukannya", Kanisius, 1998.

[3] Yuliandri, "Asas-Asas Pembentukan Peraturan Perundang-Undangan Yang Baik Dalam Rangka 
Pembuatan Undang-Undang Berkelanjutan", Dissertation, Airlangga University, 2007.

[4] Fitrani, Fitria ; Hofman, Bert and Kaiser, Kai, "Unity in diversity? The creation of new local governments in a decentralising Indonesia", Bulletin of Indonesian Economic Studies, 2005.

[5] Widiati,E. Prajwalitaand Adam, Haidar, "Pengawasan Terhadap Peraturan Kepala Daerah", Yuridika, 2012.

[6] Asshiddiqie, Jimly, "Perihal Undang-Undang, Sekretariat Jenderal Mahkamah Konstitusi", The General Secretariat of Indonesia Constitutional Court, 2005.
[7] Manan,Bagir, "Dasar-dasar Konstitusional Peraturan Perundang-undangan Nasional", Faculty of Law University of Andalas, 1994.

[8] Assidhiqqie, Jimly and Safa'at,M Ali, "Teori Hans Kelsen Tentang Hukum", The General Secretariat of Indonesia Constitutional Court, 2006. 